\title{
Penerapan Hitungan Volume Metode Simpson untuk Menghitung Volume Kapal dan Topografi Darat
}

\author{
Ni Made Rai Ratih Cahya Perbani, Rinaldy \\ Jurusan Teknik Geodesi, FTSP - Insitut Teknologi Nasional, Bandung \\ Email: ratih_c@itenas.ac.id
}

\begin{abstract}
ABSTRAK
Dalam bidang hidrografi volume kapal diperlukan untuk menentukan titik kestabilan bagi peletakan transduser alat perum gema guna memperoleh ketelitian yang lebih baik. Hitungan volume juga diperlukan untuk menentukan tebal sedimen untuk rekayasa laut. Permukaan yang akan ditentukan volumenya umumnya tidak beraturan sehingga volume ditentukan berdasarkan hasil pengukuran sehingga belum dapat diketahui secara pasti keterwakilan volume yang dihasilkan terhadap volume sebenarnya. Tujuan dari penelitian ini adalah untuk mengetahui sejauh mana volume kapal yang dihitung menggunakan aturan Simpson dapat mewakili volume yang sebenarnya sehingga dapat diterapkan pada bidang permukaan tidak beraturan seperti untuk menghitung volume topografi darat atau dasar laut. Bentuk kapal diambil bidang setengah elipsoid supaya dapat dibandingkan dengan yang sebenarnya. Volume dihitung dengan menerapkan Aturan Pertama Simpson setelah proses gridding. Setelah diketahui sifat-sifatnya maka akan dapat diterapkan pada bidang permukaan yang tidak beraturan. Dari penelitian ini diperoleh bahwa kualitas keterwakilan volume lebih ditentukan oleh terwakilinya seluruh bentuk permukaan (terutama di tempat-tempat yang ekstrem) dibandingkan dengan ukuran grid, namun pertimbangan ukuran grid diperlukan untuk efisiensi proses hitungan.
\end{abstract}

Kata kunci: volume, Aturan Pertama Simpson, ukuran grid.

\begin{abstract}
In hydrography the vessel volume is required to determine the stability point for setting up the transducer of echosounder to obtain better accuracy. Volume calculation is also required to determine thickness of sediment for marine engineering. Surface which the volume under it will be determined is generally irregular, so that the volume from the measurements will always have the uncertainty how fit it with the actual volume. This research is objected to find how the vessel volume calculated by Simpson rule can represent the actual volume so that it can be applied to irregular surface area such as land or seabed topography. Half ellipsoid is taken as the vessel ship so it can be compared with the actual. After gridding process then volume is calculated by applying Simpson First Rule. The characteristics which are found will give the consideration in application for irregular surfaces. It is found that the quality of volume representation more determined by how fit the entire surface shape (especially at extremes points) then the grid size. However, the grid size consideration is still required for efficiency in calculation.
\end{abstract}

Keywords: volume, Simpson First Rule, grid size. 


\section{PENDAHULUAN}

Thomas Simpson (1750) adalah seorang geometer masa lalu yang diyakini sebagai ilmuwan yang pertama kali memperkenalkan aturan untuk bangun ruang. Aturan Simpson untuk prismoid telah dinyatakan dalam berbagai bentuk fungsi dan umumnya dikenal dengan nama rumus prismoid [1]. Prismoid merupakan bangun ruang yang memiliki dua bidang sejajar di ujung-ujungnya. Tidak seperti prisma kedua bidang ini bisa saja tidak memililik bentuk yang sama. Bidang-bidang sisi dari prismoid ini dibentuk oleh garis-garis lurus yang saling terhubung satu sama lain dari sisi ke sisi [2].

Prismoid merupakan bentuk yang paling sering dijumpai dalam hitungan-hitungan pekerjaan yang berkaitan dengan tanah [2]. Tanah merupakan permukaan yang tidak memiliki bentuk teratur sehingga tidak dapat langsung dimodelkan dengan model matematika bentuk ideal. Untuk menghitung volume terlebih dahulu harus melalui hitungan luas terlebih dahulu. Luas bidang permukaan yang tidak beraturan dapat didekati menggunakan planimeter, aturan trapesium, aturan ordinat tengah, atau aturan Simpson. Contoh penggunaan metode ini adalah untuk rekayasa estimasi luas dari diagram indikator mesin uap, surveyor untuk estimasi luas pengeplotan tanah, atau arsitektur perkapalan untuk estimasi waterplane atau irisan mendatar kapal [3]. Contoh lainnya adalah untuk menghitung stabilitas dinamik yang memerlukan pengetetahuan luas di bawah lengkungan lengan penegak sebagai fungsi dari sudut kemiringan kapal yang disebabkan oleh pengaruh luar [4].

Ketelitian aturan Simpson dapat menyamai aturan trapesium walaupun menggunakan jumlah grid lebih sedikit. Jika dibandingkan dengan aturan trapesium maka akan lebih efisien menggunakan aturan Simpson [5]. Karenanya dalam penelitian ini akan diterapkan aturan Simpson ini dalam menghitung volume kapal seperti yang digunakan oleh [6] dalam desain hull untuk unmanned surface vehicle (USV) di perairan tenang. USV dalam bidang hidrografi digunakan untuk survei batimetri di daerahdaerah yang tidak dapat dilalui kapal besar. Tidak hanya untuk desain hull, informasi volume ini juga diperlukan bagi kapal yang sudah ada untuk menentukan titik kestabilan kapal. Jika diketahui posisi titik kestabilan kapal maka akan dapat diperoleh pertimbangan dalam meletakkan transduser alat perum gema unit luar yang digunakan untuk survei batimetri dalam rangka untuk mendapatkan ketelitian pengukuran yang lebih baik.

Dalam penelitian ini aturan Simpson juga diterapkan untuk menghitung volume topografi darat. Volume topografi darat antara lain digunakan untuk menghitung volume galian dan timbunan, sedangkan volume topografi dasar laut salah satunya dimaksudkan untuk mengetahui tebal sedimen. Informasi tebal sedimen di laut berguna antara lain sebagai pertimbangan apakah sudah diperlukan pengerukan di pelabuhan atau di kanal intake pembangkit listrik (seperti dalam penelitian [7] dalam rangka menjamin kedalaman untuk keselamatan dan keamanan.

Volume kapal yang dihitung dalam [6] merupakan volume yang diukur dari hasil pengukuran ordinat halfbreadth kapal. Pada penelitian ini bentuk kapal yang digunakan merupakan bentuk ideal, yaitu setengah elipsoid. Sungguhpun bentuk kapal pada kenyataannya tidak seperti setengah elipsoid, namun pada penelitian ini hitungan-hitungan yang diterapkan sama dengan hitungan seperti menghitung volume kapal. Karenanya tujuan dari penelitian yang dilakukan adalah untuk mengetahui sejauh mana volume kapal yang dihitung menggunakan aturan Simpson dapat mewakili volume kapal yang sebenarnya sehingga dapat diterapkan pada bidang permukaan tidak beraturan seperti untuk menghitung volume topografi darat atau dasar laut. Dengan demikian hasil penerapan aturan Simpson untuk volume dalam penelitian ini diharapkan dapat menjadi rujukan dalam menghitung volume yang lebih efisien dan teliti dalam pekerjaan-pekerjaan di bidang geodesi. 


\subsection{Volume Kapal}

\section{METODOLOGI}

\subsubsection{Desain Hull}

Kapal yang akan dihitung volumenya belum menggunakan desain hull yang sebenarnya, tapi masih diasumsikan sebagai setengah elipsoid dengan ukuran panjang, lebar, dan tinggi kapal yang sesuai dengan desain hull yang direncanakan oleh [6]. Ukuran kapal yang akan digunakan memiliki hull dengan panjang (length) $160 \mathrm{~cm}$, lebar (breadth) $50 \mathrm{~cm}$, dan kedalaman (depth) $24 \mathrm{~cm}$. Ukuran ini dikonversikan menjadi elipsoid dengan ketiga setengah sumbunya memiliki ukuran 80, 25, dan $24 \mathrm{~cm}$ seperti dapat dilihat pada Gambar 1.

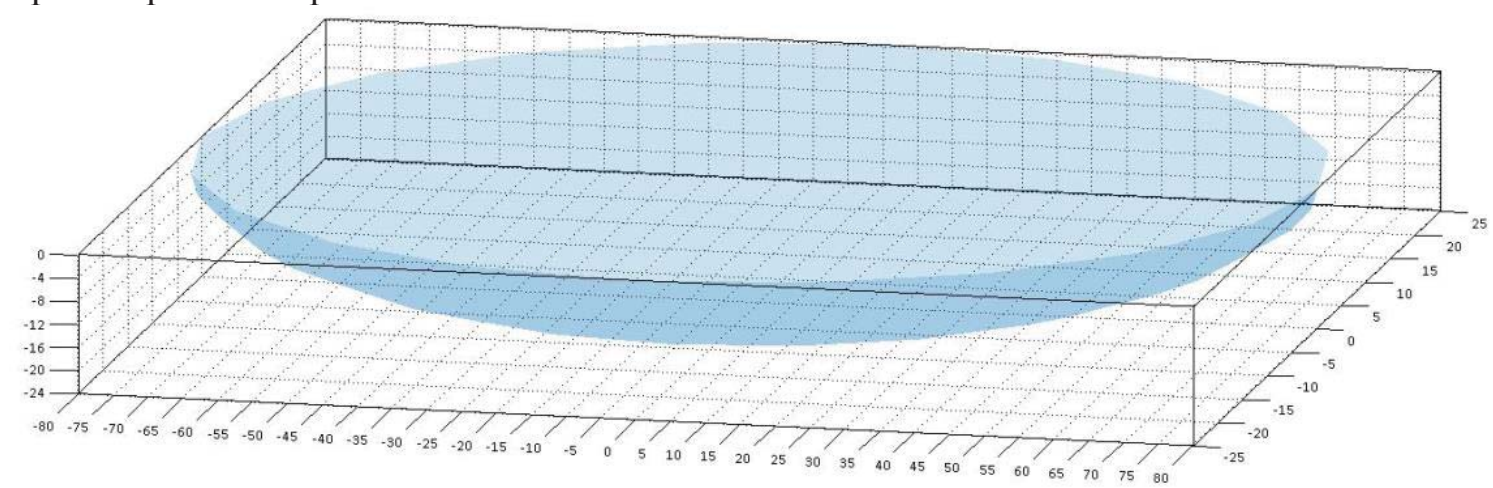

Gambar 1 Desain Hull Kapal Dengan Bentuk Setengah Elipsoid

\subsubsection{Menentukan Nilai Ordinat Quarterbreadth di Setiap Waterplane}

Dalam menerapkan aturan Simpson dilakukan proses gridding. Kedalamanan kapal sampai dengan lunasnya dibagi menjadi tujuh waterplane yang berjarak $4 \mathrm{~cm}$ seperti dapat dilihat pada Gambar 2 .

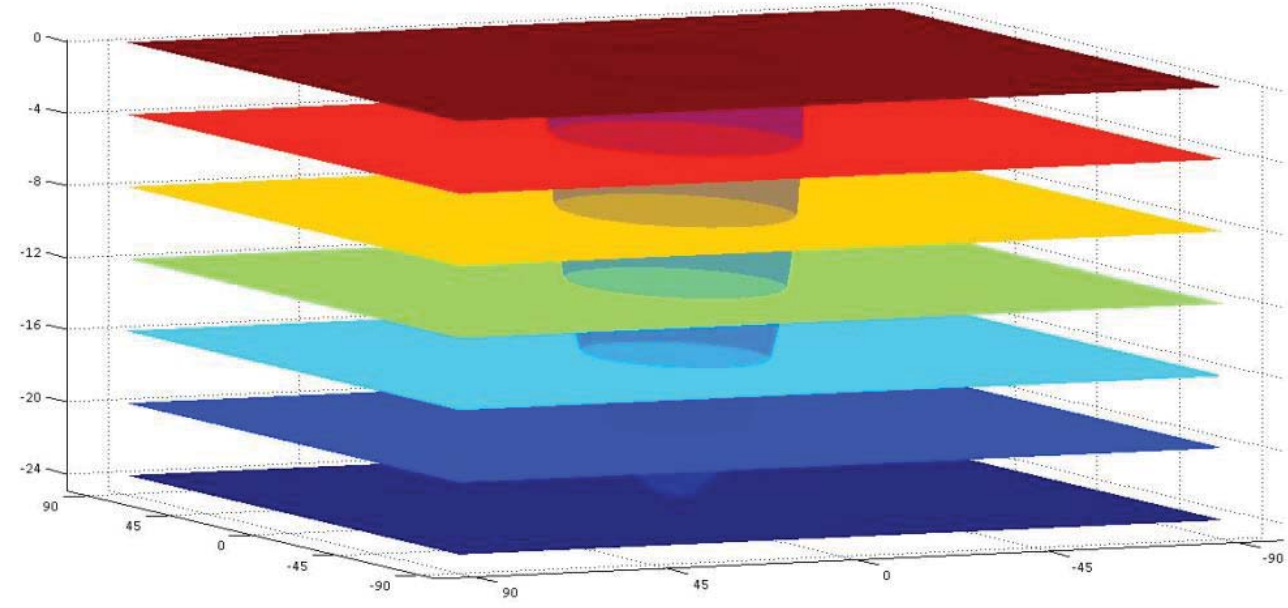

Gambar 2 Pembagian Waterplane

Irisan waterplane terhadap badan kapal yang berbentuk setengah elipsoid merupakan bidang berbentuk elips. Elips merupakan bidang yang simetris maka bidang tersebut dapat dibagi menjadi empat bagian yang sama besarnya menjadi suatu quarterbreadth pada setiap waterplane. Setiap quarterbreadth dibagi ke dalam beberapa ordinat dengan antar absis memiliki jarak sama seperti yang dapat dilihat pada Gambar 3. 


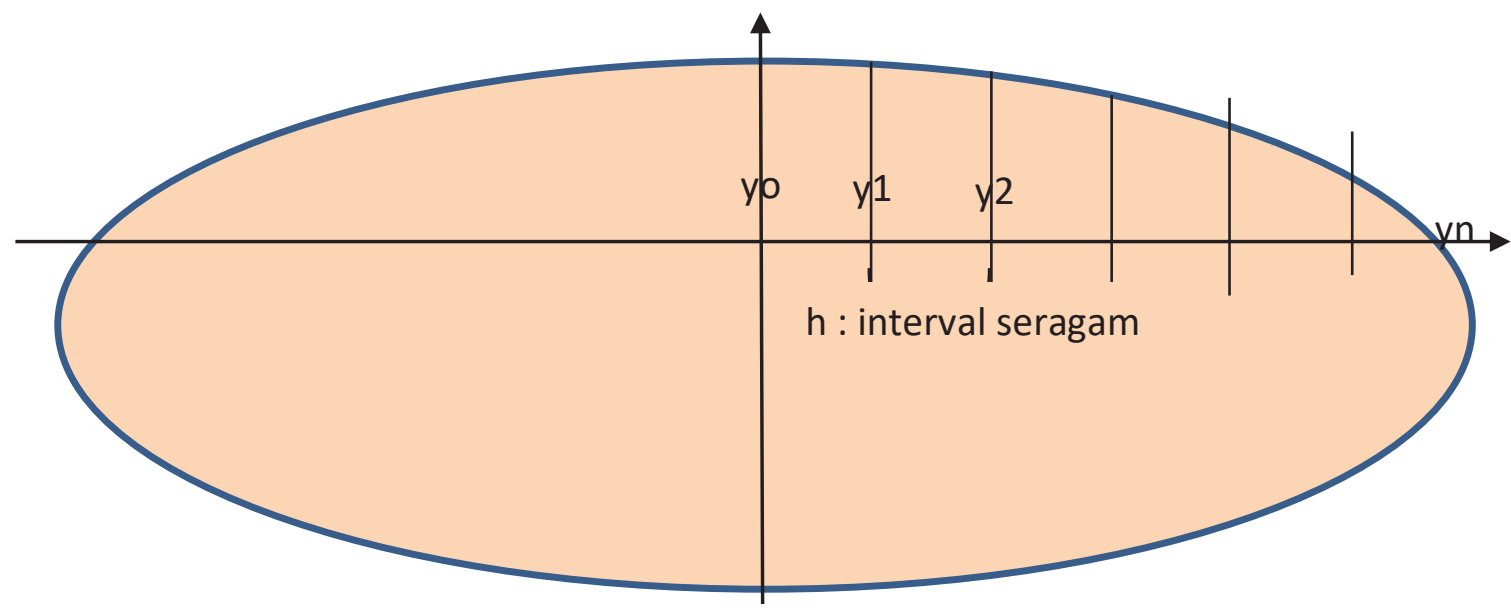

Gambar 3 Sistem Absis dan Ordinat pada Halfbreadth di Setiap Waterplane

Untuk setiap quarterbreadth absis dibagi menjadi beberapa variasi interval seragam. Nilai ordinat dari masing-masing absis dihitung berdasarkan persamaan elips dengan pusat sistem koordinat di titik $(0,0)$, yaitu: $y= \pm b \sqrt{1-\left(\frac{x^{2}}{a^{2}}\right)}$. Dalam penelitian ini hanya diambil nilai yang positif saja.

\subsubsection{Hitungan Luas pada Waterplane}

Pada quarterbreadth di setiap waterplane ordinat dibuat berjumlah ganjil maka untuk menghitung luas dapat digunakan Aturan Pertama Simpson. Berikut ini merupakan contoh hitungan luas waterplane pada depth yang dibagi dalam 16 interval seperti dapat dilihat pada Tabel 1.

Tabel 1 Hitungan Luas Waterplane pada Depth $(\mathrm{z}=0 \mathrm{~cm})$

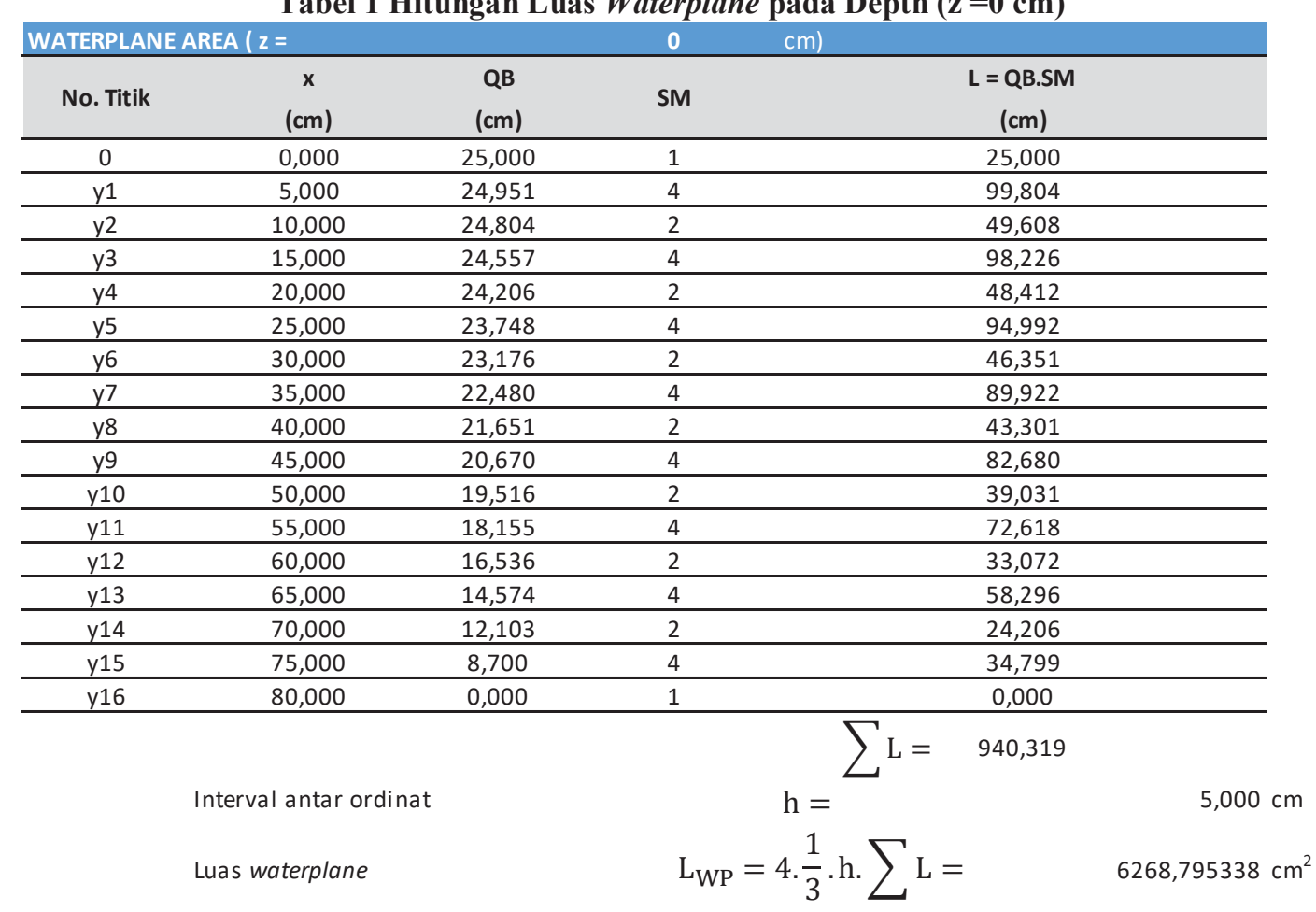

Keterangan: QB adalah ordinat-ordinat pada quarterbreadth dan SM merupakan koefisien Aturan Pertama Simpson yang merupakan pengali untuk masing-masing ordinat. 


\subsubsection{Hitungan Volume dari Lunas Hingga Depth}

Kapal umumnya memiliki bentuk yang simetris antara lambung kanan dan lambung kirinya sehingga hitungan luas dan volumenya biasanya cukup diterapkan untuk setengah badan kapal. Pada penelitian ini karena hull kapal masih diasumsikan sebagai elipsoid, tidak hanya bagian kiri dan kanan elipsoid yang simetris, tapi juga depan dan belakangnya. Dengan demikian hitungan volume diterapkan pada seperempat elipsoid terlebih dahulu dan setelahnya baru dikalikan dengan empat untuk mendapatkan volume setengah elipsoid seperti desain hull yang diterapkan.

Hitungan volume pada penelitian dilakukan dengan dua cara, yaitu dengan menghitung menggunakan rumus volume elipsoid dan dengan menerapkan Aturan Pertama Simpson. Volume-volume yang dihasilkan dari hitungan menggunakan aturan Simpson ini dibandingkan dengan volume hasil hitungan menggunakan rumus elipsoid untuk melihat sejauh mana gridding yang dilakukan memberikan besar volume yang mendekati volume setengah elipsoid yang sebenarnya.

Untuk menghitung volume kapal dari lunas ke depth digunakan Aturan Pertama Simpson untuk volume. Berikut ini merupakan contoh hitungan volume dari lunas sampai depths seperti dapat dilihat pada Tabel 2.

Tabel 3.2 Hitungan Volume dari Lunas sampai Depth

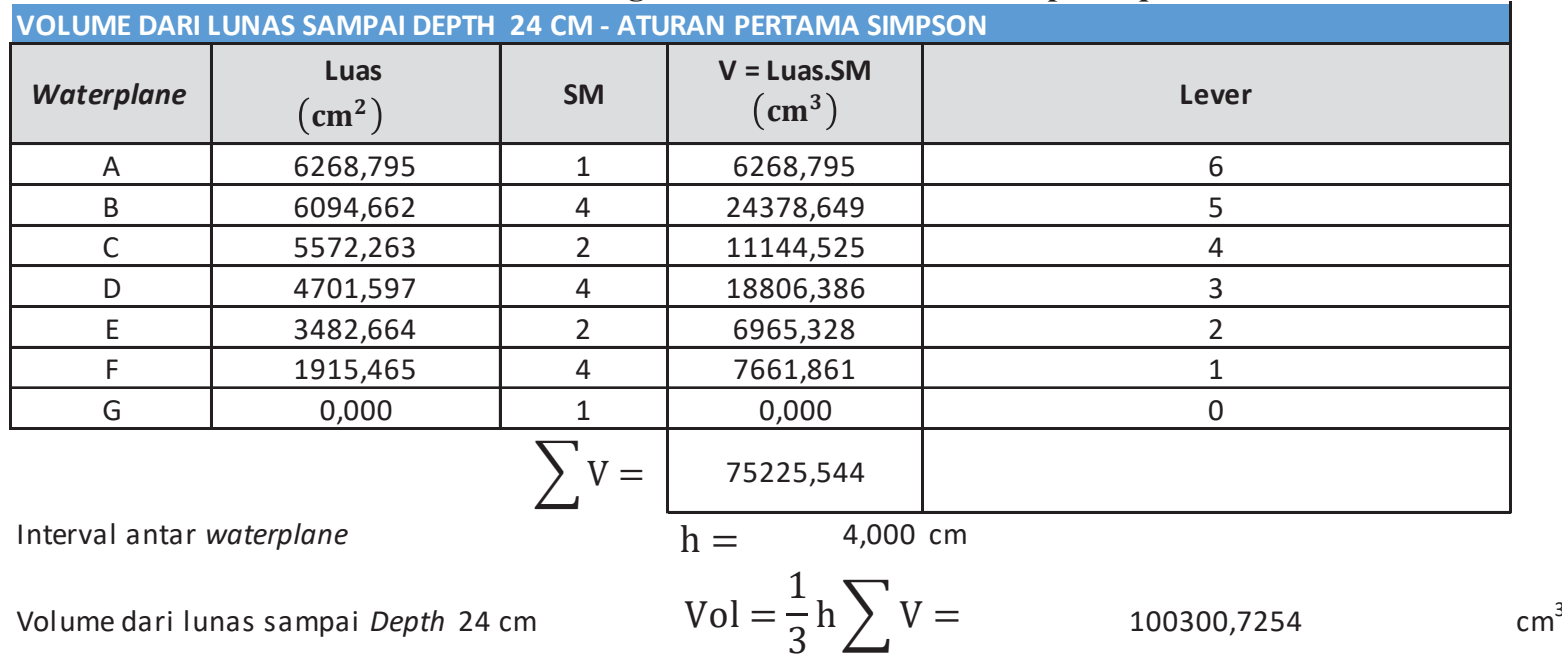

Keterangan: SM merupakan koefisien Aturan Pertama Simpson yang merupakan pengali untuk masingmasing luas waterplane

\subsection{Volume Topografi Darat}

Pada penelitian ini hitungan volume diterapkan pada topografi darat di lokasi kemah kerja Program Studi Teknik Geodesi Itenas, yaitu di Cikalong Wetan tahun 2014.

\subsubsection{Pembuatan Profil Melintang}

Tahapan dalam pembuatan profil melintang dapat dilakukan berdasarkan proses gridding. Dari label grid-grid yang telah dibuat maka label grid dapat dituangkan dalam suatu grafik dengan garis mendatar menyatakan jarak antar titik dan garis tegak menyatakan elevasinya. Profil ini bertujuan untuk menentukan elevasi titik-titik permukaan tanah sepanjang garis tertentu sehingga akan diperoleh potongan tegak (ordinat) dari dasar tertentu sepanjang garis itu. Potongan-potongan tersebut direferensikan ke Mean Sea Level (MSL). Daerah yang akan diukur volumenya dibatasi untuk luas area $100 \mathrm{~m} \times 100 \mathrm{~m}$. Profil melintang dibuat dengan selang jarak 10 meter antar profilnya. Gambaran mengenai kontur dan profil yang akan dihitung luasnya dapat dilihat pada Gambar 4 


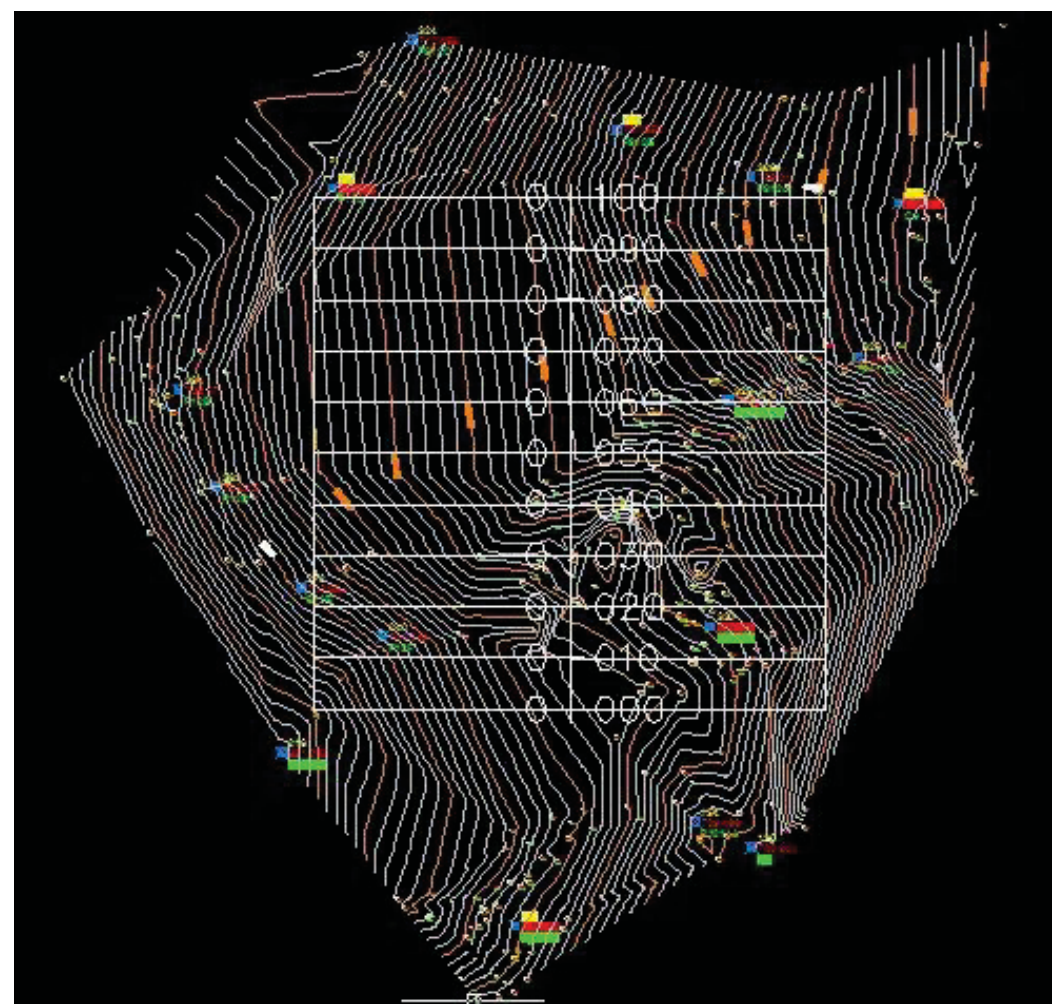

Gambar 4 Grid Profil Melintang

\subsection{Hitungan Luas pada Profil Melintang}

Setelah profil dibangun langkah selanjutnya adalah penentuan nilai ordinat berdasarkan profil yang telah dibuat. Sebagai contoh hitungan digunakan Profil Melintang 1 seperti Gambar 5.

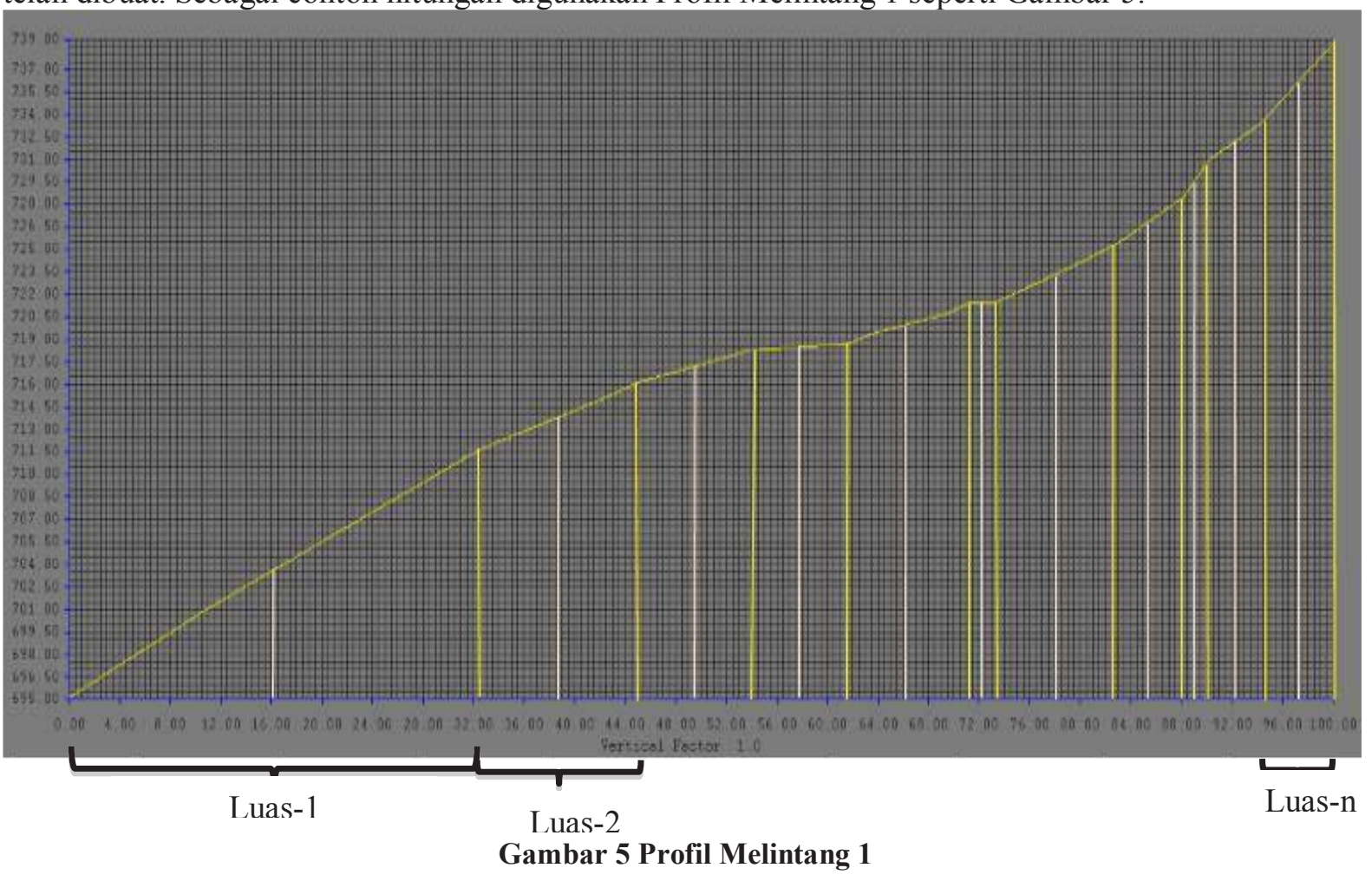

Dari Gambar 5 pada penelitian ini luas dihitung dengan bereferensikan pada MSL. Interval antar profil diusahakan sedetail mungkin dengan memperhatikan daerah-daerah ekstrem. Pada penelitian ini dalam 
satu profil diterapkan beberapa variasi interval antar ordinat supaya bentuk profil tetap dapat dipertahankan. Pada Aturan Pertama Simpson untuk menghitung luas, jumlah ordinat yang dibutuhkan berjumlah ganjil sehingga jumlah ruang partisi yang dibentuk berjumlah genap. Dapat dilihat pada Gambar 5 bahwa jumlah ordinat pada sistem absis dan ordinat diatur berjumlah ganjil dengan interval seragam maka untuk menghitung luas dapat digunakan Aturan Pertama Simpson untuk Profil Melintang 1 seperti dapat diliha pada Tabel 3.

Tabel 3 Hitungan Luas Profil Melintang 1

\begin{tabular}{cccccc}
\hline \multirow{2}{*}{ No. } & $\mathbf{H}$ & $\mathbf{y}_{\mathbf{1}}$ & $\mathbf{y}_{\mathbf{2}}$ & $\mathbf{y}_{\mathbf{3}}$ & $\mathbf{L}_{\mathbf{1}}$ \\
\cline { 2 - 6 } & $(\mathrm{m})$ & $(\mathrm{m})$ & $(\mathrm{m})$ & $(\mathrm{m})$ & $\left(\mathrm{m}^{2}\right)$ \\
\hline 1 & 16,25 & 695,00 & 703,25 & 711,50 & 22855,63 \\
\hline 2 & 6,25 & 711,50 & 713,75 & 716,00 & 8921,88 \\
\hline 3 & 4,50 & 716,00 & 717,13 & 718,25 & 6454,13 \\
\hline 4 & 3,75 & 718,25 & 718,38 & 718,50 & 5387,81 \\
\hline 5 & 4,88 & 718,50 & 720,00 & 721,50 & 7020,00 \\
\hline 6 & 1,13 & 721,50 & 721,50 & 721,50 & 1623,38 \\
\hline 7 & 4,50 & 721,50 & 723,25 & 725,00 & 6509,25 \\
\hline 8 & 2,75 & 725,00 & 726,75 & 728,50 & 3997,13 \\
\hline 9 & 1,00 & 728,50 & 729,75 & 731,00 & 1459,50 \\
\hline 10 & 2,25 & 731,00 & 732,25 & 733,50 & 3295,13 \\
\hline 11 & 2,75 & 733,50 & 736,00 & 738,50 & 4048,00 \\
\hline \multicolumn{5}{c}{ Luas (1) } & $\mathbf{7 1 5 7 1 , 8 1}$ \\
\hline \hline
\end{tabular}

Keterangan: $\mathrm{H}$ adalah interval absis pada profil melintang

\subsection{Hitungan Volume Topografi Darat}

Untuk menghitung volume topografi darat digunakan Aturan Pertama Simpson untuk rumus volume. Hasil hitungan volume topografi untuk 11 profil melintang yang memiliki interval berjarak 10 meter dapat dilihat pada Tabel 6 .

\section{HASIL DAN PEMBAHASAN}

\subsection{Luas Quarterbreadth Kapal}

Menurut [8] untuk menghitung luas, volume, dan momen dapat dilakukan menggunakan integral suatu fungsi. Tetapi, untuk bentuk badan kapal fungsi yang dibutuhkan biasanya tidak diketahui. Hal ini dapat diatasi dengan memakai integrasi numerik yang tidak membutuhkan fungsi, tetapi membutuhkan hasil pengukuran, biasanya untuk setengah lebar kapal dan atau sarat (draft). Pada penelitian ini kapal yang dihitung volumenya belum menggunakan desain hull yang sebenarnya, tapi masih diasumsikan sebagai setengah elipsoid dengan ukuran panjang, lebar, dan tinggi kapal yang sesuai dengan desain hull yang direncanakan. Penggunaan bentuk kapal yang memiliki model matematika seperti elipsoid ini dimaksudkan untuk digunakan sebagai pembanding hasil hitungan luas dan volume kapal dari proses gridding.

Elipsoid merupakan bidang yang simetrik sehingga irisan-irisan pada bidang waterplane merupakan elips. Dengan demikian bentuk setengah lebar kapal adalah setengah elips yang juga simetrik sehingga untuk hitungan luas waterplane dapat diterapkan pada seperempat elips yang menjadi quarterbreadth kapal.

Gridding diterapkan pada absis dari quarterbreadth dengan membaginya menjadi beberapa interval seragam. Dengan diterapkannya Aturan Pertama Simpson maka absis quarterbreadth dibagi dalam jumlah interval genap seperti yang diterapkan oleh [8] untuk menghitung luas halfbreadth kapal. Nilai ordinat dari setiap absis yang seharusnya merupakan hasil ukuran diperoleh melalui persamaan elips. Perbandingan hitungan luas quarterbreadth kapal dapat dilihat pada Tabel 4. 
Tabel 4 Perbandingan Luas Hasil Gridding Absis Quarterbreadth Kapal pada Depth

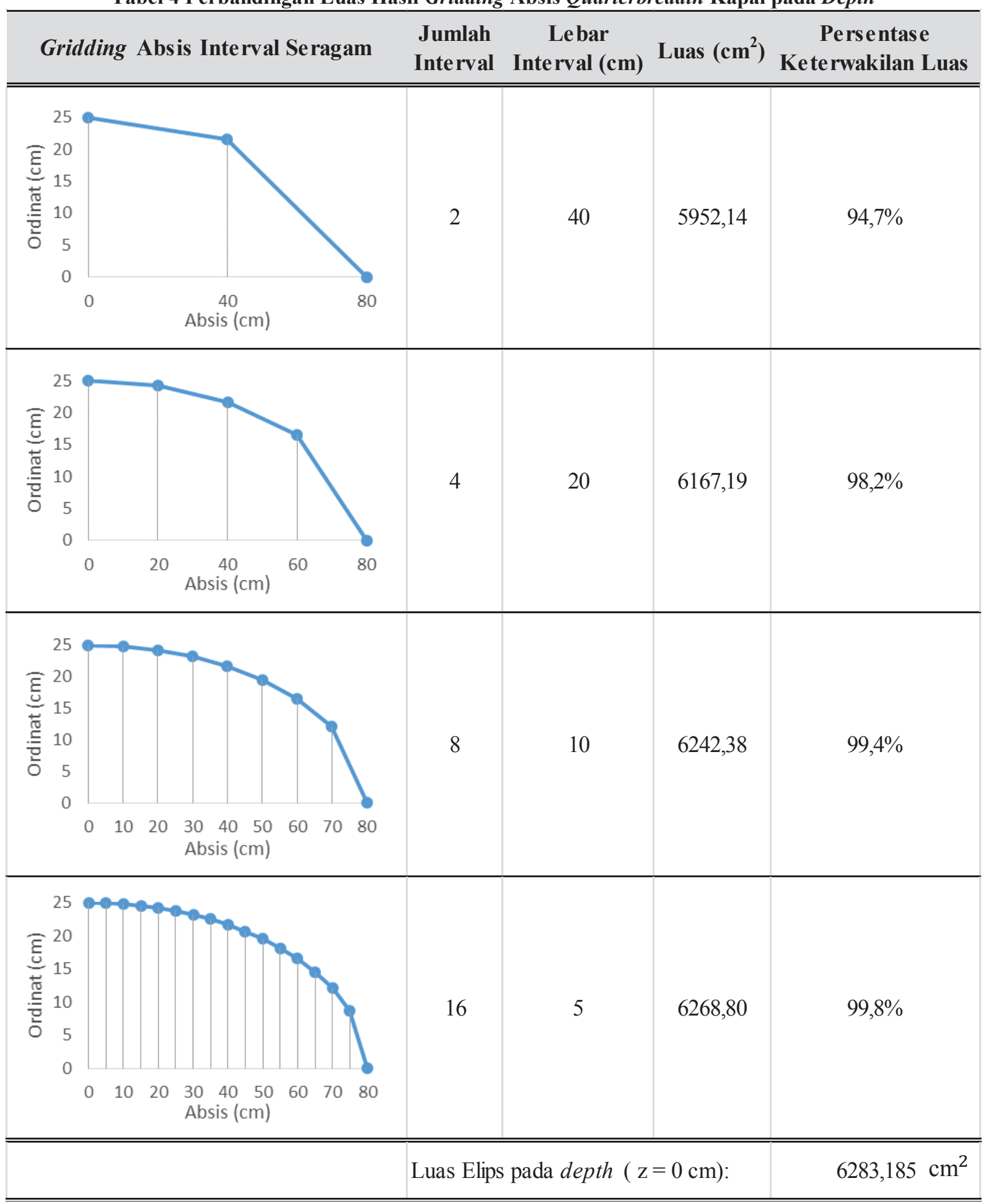

Dari Tabel 4 dapat dilihat bahwa makin rapat grid yang digunakan maka makin halus bentuk seperempat elips yang diwakili. Bentuk yang paling kasar dengan hanya membagi absis quarterbreadth menjadi dua bagian sudah mewakili lebih dari $90 \%$ luas seperempat elips yang sebenarnya. Namun, tentu saja yang diharapkan adalah sungguh-sungguh mendekati luas yang sebenarnya. Jumlah interval dua dan empat memberikan hasil keterwakilan luas elips di bawah 99\%, sedangkan untuk jumlah interval delapan dan 16 keterwakilan luas elips hampir mendekati luas yang sebenarnya. Dari hasil yang diperoleh ini dapat diketahui bahwa hitungan luas pada quarterbreadth kapal menggunakan Aturan Pertama Simpson ini dapat memberikan hasil yang baik, bahkan 
mendekati luas yang sebenarnya. Dari interval berjumlah delapan ke 16 hanya meningkatkan keterwakilan luas sebesar $0,2 \%$, padahal waktu pengukuran untuk menentukan nilai ordinat dari setiap absis menjadi dua kali lipatnya. Dengan demikian hal ini memberikan gambaran bahwa dalam menentukan luas menggunakan aturan Simpson ini bukan ukuran grid yang lebih utama, namun lebih pada sejauh mana lebar grid yang dipilih dapat menjadikan proses gridding mewakili bentuk yang sebenarnya seperti terlihat pada Tabel 4 bahwa dengan jumlah interval delapan bentuk elips sudah cukup halus. Dengan demikian untuk menghitung luas waterplane di lever yang lainnya juga diterapkan pembagian interval yang sama. Hal ini sejalan dengan pernyataan oleh [9] bahwa yang menjadi pertanyaan adalah bukan bagaimana membangun grid, tapi lebih pada berapa lama proses yang dibutuhkan. Hitungan menggunakan grid merupakan kumpulan dari sejumlah besar titik-titik di sekitar atau dalam objek. Yang paling penting adalah bahwa titik-titik tersebut berada langsung pada permukaan ataua objek untuk membantu mendefinisikan bentuknya. Pembangunan grid permukaan sebagai langkah awal untuk pembangunan grid volume tampaknya memiliki pengaruh dominan pada kualitas grid volume dan sangat memerlukan waktu.

\subsection{Volume Kapal}

Pada penelitian ini untuk menghitung volume kapal irisan waterplane terhadap badan kapal dibagi menjadi 7 lever atau 6 interval sehingga dalam menghitung volume aturan Simpson yang diterapkankan adalah aturan pertama untuk volume. Hasil perbandingan volume kapal dengan menerapkan Aturan Pertama Simpson untuk volume dapat dilihat pada Tabel 5

Tabel 5 Perbandingan Volume Kapal Menggunakan Aturan Pertama Simpson

\begin{tabular}{ccc}
\hline $\begin{array}{c}\text { Jumlah Interval } \\
\text { Setiap Waterplane }\end{array}$ & Volume $\left(\mathbf{c m}^{\mathbf{3}}\right)$ & $\begin{array}{c}\text { Persentase } \\
\text { Keterwakilan Volume }\end{array}$ \\
\hline \hline 2 & 95234,17 & $94,7 \%$ \\
\hline 4 & 98675,04 & $98,2 \%$ \\
\hline 8 & 99878,05 & $99,4 \%$ \\
\hline \hline 16 & 100300,73 & $99,8 \%$ \\
\hline \hline Luas Setengah Elipsoid: & & $100530,96 \mathrm{~cm}^{3}$ \\
\hline
\end{tabular}

Berdasarkan Tabel 5 dapat dilihat bahwa persentase keterwakilan volume kapal sejalan dengan keterwakilan luas waterplane-nya seperti yang ditunjukkan pada Tabel 4.. Dengan demikian volume kapal yang dihasilkan dari proses gridding dengan menerapkan Aturan Pertama Simpson tidak hanya bergantung pada proses gridding menjadi lever, tapi juga sangat ditentukan oleh proses gridding di setiap waterplane-nya. Dengan demikian proses ini harus diperhatikan saat diterapkan untuk menghitung volume kapal yang akan didesain dalam rangka desain hull USV di perairan tenang.

\subsection{Volume Topografi Darat}

Pada penelitian ini hitungan volume rencananya diterapkan pada topografi di lokasi kemah kerja Program Studi Teknik Geodesi Itenas, yaitu di Cikalong Wetan. Dalam menerapkan Aturan Pertama Simpson untuk menghitung luas profil juga memperhatikan keterwakilan bentuk topografi. Ukuran grid absis divariasikan sepanjang profil melintang demi terwakilinya bentuk topografi. Dengan demikian proses hitungan dilakukan dengan menghitung banyak luas asalkan interval absisnya seragam. Interval antar profil melintang profil melintang digunakan 10 meter. Hasil hitungan volume topografi di lokasi kemah kerja Pogram Studi Teknik Geodesi di Cikalong Wetan dapat dilihat pada Tabel 6. 
Tabel 6 Volume Topografi Darat Menggunakan Aturan Pertama Simpson

\begin{tabular}{|c|c|c|c|c|c|}
\hline \multirow{2}{*}{ No. } & $\mathbf{h}$ & $\mathbf{y}_{\mathbf{1}}$ & $\mathbf{y}_{\mathbf{2}}$ & $\mathbf{y}_{\mathbf{3}}$ & Volume (i) \\
\cline { 2 - 6 } & $(\mathrm{m})$ & Luas-1 $\left(\mathrm{m}^{2}\right)$ & Luas-2 $\left(\mathrm{m}^{2}\right)$ & Luas-3 $\left(\mathrm{m}^{2}\right)$ & $\left(\mathrm{m}^{3}\right)$ \\
\hline \hline 1 & 10 & 71571.8 & 71690.3 & 55110 & 1378143.438 \\
\hline 2 & 10 & 55110 & 72236.7 & 72531.3 & 1388626.979 \\
\hline 3 & 10 & 72531.3 & 72849.4 & 73083.6 & 1456708.229 \\
\hline 4 & 10 & 73083.6 & 73258.3 & 73377.5 & 1464981.146 \\
\hline 5 & 10 & 73377.5 & 73478.8 & 73482.8 & 1469250.833 \\
\hline \multicolumn{5}{|c}{ Volume Total = 7157710.625 } \\
\hline \hline \multicolumn{7}{|c|}{} \\
\hline
\end{tabular}

Keterangan: $h$ adalah interval antar profil melintang

Dari data peta kontur yang digunakan dengan kontur minor 1 meter interval terkecil sebesar 0,25 meter dan interval terbesar 20,75 meter. Hal ini disebabkan relief permukaan tanah yang tidak beraturan sehingga penerapan metode integrasi Simpson untuk hitungan luas profil mengakibatkan interval yang digunakan menjadi sangat bervariasi jaraknya agar luas yang dihasilkan akan mewakili profil dengan bentuk penampang sedekat mungkin dengan bentuk yang sebenarnya. Profil-profil yang digunakan untuk menghitung volume dibangun saling sejajar. Luas dan bentuknya tidak sama sehingga dalam menghitung volume topografi darat ini bentuknya menyerupai prismoid. Seperti yang dinyatakan oleh [2] prismoid merupakan bentuk yang paling sering dijumpai dalam hitungan-hitungan pekerjaan yang berkaitan dengan tanah. Hasil hitungan volume topografi darat seperti yang ditampilkan pada Tabel 6 tidak dapat langsung dibandingkan karena prismoid yang terbentuk memiliki profil yang tidak beraturan sehingga tidak dapat diwakili oleh model matematika ideal. Namun, pada proses gridding dalam menentukan interval absis nilai-nilai ekstrem ordinatnya sudah terwakili. Dengan demikian hasil hitungan volume untuk area yang diteliti diasumsikan sudah memiliki kualitas yang bagus.

\section{KESIMPULAN}

Berdasarkan hasil hasil penerapan Aturan Pertama Simpson untuk menghitung volume kapal berbentuk setengah elipsoid dan topografi darat didapatkan bahwa kualitas keterwakilan volume lebih ditentukan oleh terwakilinya seluruh bentuk permukaan (terutama di tempat-tempat yang ekstrem) dibandingkan dengan ukuran grid, namun pertimbangan ukuran grid diperlukan untuk efisiensi proses hitungan.

\section{DAFTAR PUSTAKA}

[1] Morris, E. (1872). "Easy Rules for the Measurement of Earthworks: By Means of the Prismoidal Formula". Philadelphia: T. R. Callender \& CO. Third Andwalnut STS.

[2] Paul, R. dan Whyte, W. (1997). "Basic Surveying 4th Edition". First Published by ButterworthHeinemann. This Edition Published 2011 by Spon Prees, 2 Park Square, Milton Park, Abingdon, Oxon OX 144 RN.

[3] Bird, J. (2014). "Understanding Engineering Mathematics". Routlegde, 2 Park Square, Milton Park, Abingdon, Oxon OX14 4RN.

[4] Biran, A. B. (2003). "Ship Hydrostatics and Stability". Butterworth-Heinemann, An Imprint of Elsevier. Linacre House, Jordan Hill, Oxford OX 2 8BP.

[5] Woodword, C. dan Philips, C. (1997). "Numerical Methods with Worked Examples". Chapman and Hall, 2-6 Boudary Row, London SE1 8HN, U. K.

[6] Azmar, Z. B. dan Perbani, N. M. R. R. C. (2016). "Studi Awal Desain Hull USV (Unmanned Surface Vehicle) untuk Pengukuran Batimetri di Perairan Tenang". Jurnal Online Itenas Reka Geomatika, Vol. 2016 No.1, Maret 2016, p. 42-51 ISSN: 2338-350X 
[7] Arianto, J. (2015). "Analisis Luas dan Volume Sedimen pada Kanal Intake untuk Menjaga Ketersediaan Pasokan Air (Studi Kasus : PLTGU Muara Tawar, Bekasi Utara)". Skripsi Program Studi Teknik Geodesi, Jurusan Teknik Geodesi, Fakultas Teknik Sipil dan Perencanaan, Institut Teknologi Nasional, Bandung.

[8] Tupper, E.C. dan K.J. Rawson. (1968). Basic Ship Theory, Combined Volume. Butterworth Heinemann.

[9] Smith, R. E. (1992). "Software Surface Modeling and Grid Generation Steering Committee". National Aeronautics and Space Administration (NASA), USA. 